\title{
Pengaruh Keputusan Investasi Dan Makro Ekonomi Melalui Operasional Terhadap Nilai Perusahaan
}

\author{
Lu'lu'il Maknuun \\ Institut Pesantren KH. Abdul Chalim \\ luluilmaknuun92@gmail.com
}

\begin{abstract}
This study aims to determine and analyze the effect of investment decisions and macroeconomics through operations to firm value. This study uses a quantitative approach. the data analysis method used in this study is the Smart Partial Least Square (PLS) software. The effect of investment decisions on operations, the relationship between the two variables is a significant negative. The effect of investment decisions with firm value, the relationship between the two variables is significantly positive. The influence of macroeconomics on operations, the relationship between the two is negative is not significant. The influence of macroeconomic with firm value, the relationship between two variables is not significant positive. The operational effect on firm value, the relationship between the two variables is significantly positive.
\end{abstract}

Keyword : Investment Decisions, Macroeconomics, Operation, Firm Value.

\section{PENDAHULUAN}

Perkonomian di Indonesia mengalami pertumbuhan dari waktu ke waktu yang sejalan dengan era globalisasi ekonomi sehingga mengakibatkan semakin ketatnya persaingan diantara perusahaan dalam meningkatkan kinerja perusahaan untuk mencapai tujuan yang diinginkan. Perusahaan senantiasa dituntut untuk dapat selalu meningkatkan nilai perusahaan dengan pengelolaan dan penentuan secara tepat terhadap sumber dana. Situasi persaingan bisnis yang semakin ketat mengharuskan perusahaan mencari tambahan dana untuk kelangsungan hidupnya. Perusahaan harus berusaha menarik para investor supaya bersedia menanamkan modalnya kedalam perusahaan.

Para investor tentunya harus jeli dalam memilih perusahaan yang akan dipilihnya dalam berinvestasi supaya dikemudian hari tidak mengalami kerugian. Investasi yang dilakukan oleh para investor harus selalu didasarkan pada pertimbangan rasional, sehingga berbagai jenis informasi sangat diperlukan dalam pengambilan keputusan untuk berinvestasi. Para pengambil keputusan yang mana para investor yang menanamkan modalnya harus berfikir berdasarkan akal sehat dengan didasari literasi keuangan perusahaan yang didapatkan dari informasi-informasi terkait perusahaan. Putra, dkk $(2016 ; 271)$

Perusahaan yang telah go public harus mampu memformulasikan strategi secara tepat melalui pertimbangan analisis informasi yang ada sehingga dapat menciptakan nilai perusahaan yang baik. Informasi yang lazim digunakan 
dikelompokkan menjadi dua yaitu informasi yang bersifat fundamental dan teknikal. Informasi fundamental merupakan analisis yang dilakukan dengan menggunakan data internal keuangan perusahaan untuk menghitung nilai intrinsik saham. Informasi yang bersifat teknikal diperoleh dari eksternal perusahaan yaitu, ekonomi, sosial dan budaya, politik, teknologi dan lainnya. Makro ekonomi merupakan salah satu informasi teknikal. Jogiyanto (2008)

Makro ekonomi dapat dikatakan sebagai determinan dari faktor fundamental yang dapat mempengaruhi kebijakan manajer dalam menentukan kebijakan fundamental dan sekaligus menjadi faktor yang mempengaruhi firm value. Analisis fundamental memusatkan perhatiannya pada data-data laporan keuangan yang dikeluarkan oleh perusahaan, Namun keuangan tidak hanya ditentukan oleh kegiatan operasional perusahaan saja, tapi ada makro ekonomi yaitu exchange rate dan inflasi. Apabila exchange rate berfluktuasi dan inflasi meningkat maka tentunya kondisi fundamental perusahaan akan melemah sehingga mempengaruhi nilai firm value perusahaan. Muh Nurrohim (2013)

Perusahaan harus tetap menjaga dan meningkatkan firm value. Nilai perusahaan itu sendiri merupakan kinerja yang dilakukan oleh manajemen untuk menarik para investor terhadap perusahaan. Pemilik perusahaan dan steakholder yang ada harus berusaha sekuat tenaga untuk menunjukkan kepada para investor agar memilih bahwa perusahaannya merupakan salah satu alternatif untuk berinvestasi.

Hidayat (2010) menyatakan bahwa keputusan investasi merupakan faktor penting dalam fungsi keuangan perusahaan, dimana nilai perusahaan ditentukan oleh keputusan investasi. Hal ini sesuai dengan penelitian yang dilakukan oleh Ayu Tiarawati (2015) Hasil uji hipotesis menunjukkan bahwa keputusan investasi berpengaruh terhadap nilai perusahaan. Selain itu Wahyudi dan Pawestri (2006) menemukan bahwa keputusan investasi tidak berpengaruh terhadap nilai perusahaan.

Penelitian Erni Indah Sari (2011) menunjukkan bahwa tidak ada pengaruh antara inflasi dan tingkat suku bunga terhadap return saham. Tetapi Witha Dwipartha (2013) dan Ni Made (2013) menyatakan bahwa faktor ekonomi makro berpengaruh positif dan tidak signifikan terhadap nilai perusahaan. Dan menurut Samuelson (2005) terdapat hubungan positif antara inflasi dengan harga saham.

Penelitian ini tidak hanya menggunakan faktor keputusan investasi dan makroekonomi saja yang berpengaruh terhadap nilai perusahaan, namun peneliti juga melihat dari sudut pandang operasional perusahaan yang digunakan untuk memediasi hubungan pengaruh keputusan investasi dan makroekonomi terhadap nilai perusahaan.

Berdasarkan latar belakang yang telah diuraikan maka tujuan dalam penelitian ini adalah menjelaskan pengaruh keputusan investasi terhadap operasional, nilai perusahaan, menjelaskan pengaruh makro ekonomi terhadap operasional, nilai perusahaan, dan menjelaskan pengaruh operasional terhadap nilai perusahaan. 


\section{PERUMUSAN HIPOTESIS}

Berikut hasil pengembangan hipotesis yang dikaji berdasarka literatul penelitian terdahulu:

\section{a. Keputusan investasi terhadap operasional}

Penelitian Apri Daryanti (2012) menunjukkan pengaruh modal kerja dan total asset turnover terhadap profitabilitas memberikan hasil bahwa total asset turnover memiliki pengaruh yang signifikan terhadap profitabilitas pada PT Metrodata Electronics Tbk. Selain itu Setiani (2012) juga menyatakan bahwa keputusan investasi berpengaruh secara langsung terhadap besarnya rentabilitas investasi dan aliran kas perusahaan dimasa-masa yang akan datang.

$\mathrm{H}_{0} 1$ : Keputusan investasi berpengaruh signifikan terhadap operasional.

\section{b. Keputusan investasi terhadap nilai perusahaan}

Nilai perusahaan semata-mata ditentukan oleh keputusan investasi. nilai perusahaan yang dibentuk mellaui indikator nilai pasar saham sangat dipengaruhi oleh peluang-peluang investasi, Wahyudi dan Pawestri (2006). sesuai dengan wijaya dan wibawa (2010) yang memberikan konfirmasi empiris bahwa kepurusan investasi berpengaruh positif terhadap nilai perusahaan. pernyataan sesuai dengan penelitian yang dilakukan oleh Arie dan Abdul bahwa terdapat pengaruh positif dan signifikan keputusan investasi terhadap nilai perusahaan.

$\mathrm{H}_{0} 2$ : Keputusan investasi berpengaruh signifikan terhadap nilai perusahaan.

\section{c. Makro ekonomi terhadap operasional}

Nijam (2015) menyatakan bahwa investor akan cenderung mengevaluasi faktor makro ekonomi karena kondisi makro ekonomi berpotensi signifikan dalam menentukan arah dann kondisi pasar modal. menurut Andri (2014) variabel makro ekonomi perlu diperhatikan karena variabel makro ekonomi mempengaruhi operasi perusahaan sehari-hari. Sesuai dengan Sujoko (2017) menyatakan bahwa suku bunga berpengaruh terhadap operasional karena suku bunga adalah biaya modal bagi perusahaan.

$\mathrm{H}_{0} 3$ : Makro ekonomi berpengaruh signifikan terhadap operasional.

\section{d. Makro ekonomi terhadap nilai perusahaan}

Ni made witha (2012) menyatakan bahwa faktor makro ekonomi dengan indikator suku bunga yang tinggi, laju inflasi yang tinggi dan fluktuasi nilai tukar yang tinggi menyebabkan perusahaan mengalami kesulitan keuangan yang dapat menurunkan kinerja keuangannya sehingga dapat berdampak pada turunnya nilai perusahaan. Witha Dwipartha (2013) dan Ni Made (2013) menyatakan bahwa 
faktor ekonomi makro berpengaruh positif dan tidak signifikan terhadap nilai perusahaan. Dan menurut Samuelson (2005) terdapat hubungan positif antara inflasi dengan harga saham.

$\mathrm{H}_{0} 4$ : Makro ekonomi berpengaruh signifikan terhadap nilai perusahaan.

\section{e. Operasional terhadap nilai perusahaan}

Nitariana (2016) yang menyatakan terdapat pengaruh yang signifikan operasional terhadap nilai perusahaan. Didukung juga oleh Halim (2015) yang menyatakan bahwa ada pengaruh operasional terhadap nilai perusahaan, karena jika perusahaan besar membutuhkan dana yang besar untuk menunjang operasional. Pada penelitian Ardianti Fajriana (2016) keputusan investasi berpengaruhterhadap nilai perusahaan

$\mathrm{H}_{0} 5$ : Operasional berpengaruh signifikan terhadap nilai perusahaan.

\section{METODE PENELITIAN}

Jenis penelitian ini adalah causality research. Causality adalah hubungan dalam perubahan pada suatu variabel sebab perubahan atau pengaruh variabel lain (Patzer, 1996: 6). Sedangkan causality research sendiri adalah suatu penelitian yang menjelaskan hubungan dalam perubahan suatu variabel sebab perubahan variabel lain. Sampel yang digunakan dalam penelitian ini adalah perusahaan yang terdaftar pada indeks LQ45 pada tahun 2017-2019.

Jenis data yang digunakan dalam penelitian ini adalah data sekunder. Data sekunder merupakan sumber data yang tidak memberikan informasi secara langsung kepada yang mengumpulkan data. metode yang digunakan dalam mengumpulkan data pada penelitian ini adalah documented method, yaitu mendapatkan informasi atau data yang diperlukan melalui laporan tahunan perusahaan dan ICMD 2017-2019 dengan indek LQ45 sebagai batasan sampel sehingga dapat dianalisis guna menemukan suatu hasil dan kesimpulan.

Analisis data dalam penelitian ini menggunakan SEM (Structural Equation Modelling) dengan aplikasi program PLS (Partial Least Square) versi 3.0 M3 yang mana dikembangkan pertama kali oleh wold sebagai metode umum untuk mengestimasi path model yang menggunakan konstruk laten dengan mutiple indikator. PLS (Partial Least Square) merupakan factor indeterminacy dengan metode analisis yang powerful, karena data tidak harus diasumsikan dengan pengukuran skala tertentu, jumlah sampelnya juga sedikit. PLS juga dapat digunakan untuk konfirmasi teori.

Berdasarkan tujuan penelitian maka rancangan uji hipotesis dalam penelitian ini dapat dibuat sesuai dengan tujuan penelitian. Tingkat kepercayaan yang digunakan adalah 95\%, sehingga tingkat presisi atau batas ketidak akuratan sebesar $(\alpha)=5 \%=0,05$. Dan menghasilkan nilai t-tabel sebesar 1,96. Sehingga 
jika nilai t-statistik lebih kecil dari t-tabel [t-statistik < 1,96], maka H0 diterima dan Ha ditolak dan jika nilai t-statistik lebih besar atau sama dengan t-tabel [ $\mathrm{t}$ statistik > 1,96], maka Ho ditolak dan Ha diterima.

\section{HASIL DAN PEMBAHASAN}

4.1 Hasil Penelitian

Tabel

Rekapitulasi Hasil Penelitian

\begin{tabular}{|l|l|l|l|}
\hline \multicolumn{1}{|c|}{$\begin{array}{c}\text { Pengaruh Antar } \\
\text { Variabel }\end{array}$} & Koefisien Jalur & \multicolumn{1}{|c|}{ T Statistics } & \multicolumn{1}{|c|}{ Keterangan } \\
\hline $\begin{array}{l}\text { Keputusan } \\
\text { Investasi -> Nilai } \\
\text { Perusahaan }\end{array}$ & 0.627 & 6.917 & Signifikan \\
\hline $\begin{array}{l}\text { Keputusan } \\
\text { Investasi } \\
\text { Operasional }\end{array}$ & -0.715 & 8.801 & Signifikan \\
\hline $\begin{array}{l}\text { Makro Ekonomi -> } \\
\text { Nilai Perusahaan }\end{array}$ & 0.057 & 1.715 & Tidak Signifikan \\
\hline $\begin{array}{l}\text { Makro Ekonomi -> } \\
\text { Operasional }\end{array}$ & -0.071 & 1.013 & Tidak Signifikan \\
\hline $\begin{array}{l}\text { Operasional -> } \\
\text { Nilai Perusahaan }\end{array}$ & 0.285 & 2.268 & Signifikan \\
\hline
\end{tabular}

Sumber: Hasil olah analisis PLS

a. Pengaruh Keputusan Investasi Terhadap Operasional

Hubungan antara keputusan nvestasi (X1) dengan operasional (Z1) adalah signifikan dengan t-statistik sebesar 8,801(>1,96). Nilai original sample estimate yaitu sebesar $-0,715$ yang menunjukkan bahwa arah hubungan antara keputusan investasi (X1) dengan operasional (Z1) adalah negatif, dapat diartikan bahwa keputusan investasi yang merupakan maslah bagaimana manajer keuangan harus mengalokasikan dana ke dalam bentuk-bentuk investasi yang akan dapat mendatangkan keuntungan dimasa yang akan datang dan dapat menjadi batasan yang dijadikan sebagai pedoman untuk melakukan suatu kegiatan.

Hal ini menunjukkan bahwa keputusan investasi dapat diketahui dari aktiva perusahaan. Struktur kekayaan perusahaan akan dipengaruhi oleh perbandingan antara current assets yang didalamnya terdapat kas, piutang, investasi jangka pendek, persediaan, beban dibayar dimuka dan fixed assets yang merupakan aset berwujud yang diperoleh dalam keadaan siap pakai yang digunakan dalam operasi perusahaan yang mana tidak untuk dijual dalam rangka kegiatan normal perusahaan dan mempunyai masa manfaat lebih dari satu tahun. Hubungan negatif ini dapat diinterpetasikan dimana ketika fungsi manajemen dalam melakukan keputusan investasi yang terlalu besar akan mengganggu operasional perusahaan. 
Penelitian Apri Daryanti (2012) menunjukkan pengaruh modal kerja dan total asset turnover terhadap profitabilitas memberikan hasil bahwa total asset turnover memiliki pengaruh yang signifikan terhadap profitabilitas pada PT Metrodata Electronics Tbk. Selain itu Setiani (2012) juga menyatakan bahwa keputusan investasi berpengaruh secara langsung terhadap besarnya rentabilitas investasi dan aliran kas perusahaan dimasa-masa yang akan datang.

\section{b. Pengaruh Keputusan Investasi Terhadap Nilai Perusahaan}

Berdasarkan hasil analisis statistik inferensial diperoleh bukti bahwa hubungan antara keputusan investasi (X1) dengan nilai perusahaan (Y) adalah signifikan dengan t-statistik sebesar 6,917 $(>1,96)$. Nilai original sample estimate sebesar 0,627 yang menunjukkan bahwa arah hubungan antara keputusan investasi (X1) dengan nilai perusahaan (Y) adalah positif.

Pada penelitian Ayu Tiarawati (2015) dengan judul pengaruh keputusan investasi, keputusan pendanaan, kebijakan deviden dan pengungkapan corporate social responsibility terhadap nilai perusahaan. Hasil penelitian menunjukkan bahwa koefisien determinasi diperoleh nilai sebesar 0,366 yang berarti bahwa $36,6 \%$ nilai perusahaan dipengaruhi oleh keputusan investasi, keputusan pendanaan, kebijakan deviden dan pengungkapan corporate social responsibility sisanya sebanyak $63,4 \%$ yang dipengaruhi oleh variabel diluar model. Hasil uji hipotesis menunjukkan bahwa keputusan investasi, keputusan pendanaan dan kebijakan deviden berpengaruh terhadap nilai perusahaan, sedangkan corporate social responsibility tidak berpengaruh terhadap nilai perusahaan, maka dengan demikian penelitian Ayu Tiarawati (2015) mendukung penelitian ini. Selain itu Arie Afzal (2012) dan Abdul Rohman (2012) juga mengungkapkan bahwa keputusan investasi berpengaruh terhadap nilai perusahaan.

\section{c. Pengaruh Makro Ekonomi Terhadap Operasional}

Berdasarkan hasil analisis statistik inferensial diperoleh bukti bahwa hubungan antara makro ekonomi (X2) dengan operasional (Z1) adalah tidak signifikan dengan t-statistik sebesar $1,013(<1,96)$. Nilai original sample estimate sebesar- 0,071 yang menunjukkan bahwa arah hubungan antara makro ekonomi (X2) dengan operasional (Z1) adalah negatif. Dimana makro ekonomi merupakan bagian dari ilmu ekonomi yang mengharuskan mempelajari mekanisme bekerjanya perekonomian secara keseluruhan akan inflasi, nilai tukar, dan suku bunga yang mana saat makro ekonomi suatu negara mengalami kenaikan bisa jadi operasional perusahaan menjadi lemah karena saham dalam perusahaan juga mengalami perubahan sehingga operasional perusahaan menjadi pantauan khusus dalam internal perusahaan.

Sesuai dengan pernyataan Nijam (2015) menyatakan bahwa investor akan cenderung mengevaluasi faktor makro ekonomi karena kondisi makro ekonomi berpotensi signifikan dalam menentukan arah dann kondisi pasar modal. menurut 
Andri (2014) variabel makro ekonomi perlu diperhatikan karena variabel makro ekonomi mempengaruhi operasi perusahaan sehari-hari. Hasil penelitian ini didukung Sujoko (2017) menyatakan bahwa suku bunga berpengaruh terhadap operasional karena suku bunga adalah biaya modal bagi perusahaan.

\section{d. Pengaruh Makro Ekonomi Terhadap Nilai Perusahaan}

Berdasarkan hasil analisis statistik inferensial diperoleh bukti bahwa hubungan antara makro ekonomi (X2) dengan nilai perusahaan (Y) adalah tidak signifikan dengan t-statistik sebesar 1,715 $(<1,96)$. Nilai original sample estimate sebesar 0,057 yang menunjukkan bahwa arah hubungan antara makro ekonomi (X2) dengan nilai perusahaan (Y) adalah positif. Inflasi terjadi karena adanya kenaikan biaya produksi. Makro ekonomi yang diukur dengan inflasi memberikan gambaran akibat inflasi krena biaya produk dimana kenaikan pada biaya produksi terjadi akbat kenaikan harga-harga bahan baku, misalnya karena keberhasilan serikat buruh dalam menaikkan upah atau karena kenaikan harga bahan bakar minyak. Kenaikan biaya produksi mengakibatkan harga naik maka terjadilah inflasi. Arah hubungan antara makro ekonomi (X2) dengan nilai perusahaan (Y) adalah negatif yang mana dapat diartikan bahwa saat makro ekonomi mengalami kenaikan maka nilai perusahaan juga akan mengalami kenaikan.

Pada penelitian Erni Indah Sari (2011) yang berjudul pengaruh inflasi dan tingkat suku bunga terhadap Return saham PT Indofood Sukses Makmur Tbk. Hasil penelitiannya menunjukkan bahwa tidak ada pengaruh antara inflasi dan tingkat suku bunga terhadap Return saham PT Indofood Sukses Makmur Tbk baik secara simultan maupun parsial dengan demikian penelitian ini mendukung. Witha Dwipartha (2013) dan Ni Made (2013) menyatakan bahwa faktor ekonomi makro berpengaruh positif dan tidak signifikan terhadap nilai perusahaan. Dan menurut Samuelson (2005) terdapat hubungan positif antara inflasi dengan harga saham.

e. Pengaruh Operasional Terhadap Nilai Perusahaan

Berdasarkan hasil analisis statistik inferensial diperoleh bukti bahwa hubungan operasional (Z1) dengan nilai perusahaan (Y) adalah signifikan, dengan t-statistik sebesar 2,268 $(>1,96)$. Nilai original sample estimate adalah positif, yaitu sebesar 0,285 yang menunjukkan bahwa arah hubungan antara makro ekonomi (X2) dengan nilai perusahaan (Y) adalah positif.

Hasil penelitian ini didukung oleh Nitariana (2016) yang menyatakan terdapat pengaruh yang signifikan operasional terhadap nilai perusahaan. Didukung juga oleh Halim (2015) yang menyatakan bahwa ada pengaruh operasional terhadap nilai perusahaan, karena jika perusahaan besar membutuhkan dana yang besar untuk menunjang operasional.

Pada penelitian Ardianti Fajriana (2016) pengaruh corporate social responsibility (CSR), keputusan investasi dan struktur modal terhadap nilai 
perusahaan dengan kepemilikan manajerial sebagai variabel pemoderasi yang memberikan hasil penelitian bahwa :

1) corporate social responsibility (CSR) berpengaruh positif dan tidak signifikan terhadap nilai perusahaan dengan nilai sig. 0,236 (0,236> 0,005)da nilai t-hitung $1,195<\mathrm{t}$-tabel 1,666 .

2) keputusan investasi berpengaruh positif dan signifikan terhadap nilai perusahaan dengan nilai sig. $0,000(0,000<0,005)$ dan nilai t-hitung $15,902>$ t-tabel 1,666 .

3) struktur modal berpengaruh negatif dan signifikan terhadap nilai perusahaan dengan nilai sig. $0,028(0,028<0,005)$ dan nilai t-hitung $2,238>$ t-tabel $-1,666$.

4) kepemilikan manajerial mampu memoderasi pengaruh corporate social responsibility (CSR) terhadap nilai perusahaan dengan nilai sig. 0,002 $(0,002<0,005)$ dan nilai t-hitung 3,143> t-tabel 1,993.

5) kepemilikan manajerial mampu memoderasi pengaruh keputusan investasi terhadap nilai perusahaan dengan nilai sig. $0,009 \quad(0,009<$ 0,005) dan nilai t-hitung 2,705> t-tabel 1,993.

6) kepemilikan manajerial tidak mampu memoderasi pengaruh struktur modal terhadap nilai perusahaan dengan nilai sig. $0,525(0,525>$ $0,005)$ dan nilai t-hitung $0,638<$ t-tabel 1,993 .

7) corporate social responsibility (CSR), keputusan investasi dan struktur modal secara bersama-sama berpengaruh terhadap nilai perusahaan dengan nilai sig. 0,000 $(0,000<0,005)$ dan nilai F-hitung 84,924 > F-tabel 2,500.

\section{KESIMPULAN}

Berdasarkan hasil pengujian dan pembahasan megenai pengaruh keputusan investasi dan makro ekonomi melalui operasional terhadap nilai perusahaan adalah sebagai berikut:

a. Pengaruh variabel keputusan investasi terhadap operasional memiliki hubungan yang negatif signifikan. Keputusan investasi merupakan gambaran dari suatu perusahaan yang dapat dilihat dari asetnya, dimana operasional suatu perusahaan akan menurun apabila manajemen mengambil keputusan investasi yang terlalu tinggi.

b. Variabel keputusan investasi terhadap nilai perusahaan memiliki hubungan yang positif signifikan. Dimana nilai perusahaan dapat dikatakan baik apabila modal suatu perusahaan besar. 
c. Makro ekonomi memiliki pengaruh yang negatif tidak signifikan terhadap operasional. Dimana apabila terjadi inflasi yang begitu besar maka suatu perusahaan akan mengalami penurunan.

d. Makro ekonomi memiliki pengaruh positif tidak signifikan terhadap nilai perusahaan. Dimana makro ekonomi yang dilihat dari inflasi akan menaikkan biaya dan memberikan dampak pada perusahaan, nilai perusahaan akan naik apabila inflasi akan naik.

e. Operasional memiliki pengaruh yang positif signifikan terhadap nilai perusahaan yang dapat diinterprestasikan bahwa operasional perusahaan yang ditinjau dari profit perusahaan dan pada saat operasional perusahaan mengalami kenaikan maka nilai perusahaan juga ikut naik.

\section{UCAPAN TERIMA KASIH}

Untuk dapat menyelesaikan penelitian ini, penulis mendapatkan berbagai bantuan dari beberapa pihak. Oleh karena itu penulis berkewajiban menyampaikan rasa terima kasih sedalam-dalamnya, terutama kepada: Rektor Institut Agama Islam Pangeran Diponegoro (IAI PD) Nganjuk yang telah memberikan izin kepada penulis untuk dapat menyelesaikan studi akhir. Dekan Fakultas Syariah dan Ekonomi Islam, yang telah memberikan izin dan pengarahan pada penulis akhir studi ini. Dan para pembimbing yang telah memberikan bimbingan dengan penuh kesabaran sehingga dapat terselesaikannya penulisan ini.

\section{REFERENSI}

Apri Daryanti, Pengaruh Modal kerja dan Total Asset Turnover Terhadap Profitabilitas: Studi kasus pada PT Metrodata Elektronics Tbk. Universitas Komputer Indonesia.

Afzal, Arie;Abdul Rahman. 2012. Pengaruh keputusan investasi, keputusan pendanan, dan kebijakan deviden terhadap nilai perusahaan. Diponegoro Jurnal of Accounting Vol 1 Nomor2.

Boediono. 1998. Ekonomi Moneter. Yogyakarta. BPFE.

Brigham F. Eugene and Joul F. Houston, 1998. Fundamentals of Financial Management. Eight Edition. New York : The Dryden Press. Harcourt Branco College Publishers.

Cheng, Megawati dan Christiawan, Yulius Jogi, 2011. Pengaruh Pengungkapan Corporate Social Responsibility Terhadap Abnormal Return. Jurnal Akuntansi dan Keuangan No.1 Vol.13.

Darminto, 2008. Pengaruh Faktor Eksternal dan Berbagai Keputusan Keuangan Terhadap Nilai Perusahaan. Jurnal Aplikasi Manajemen vo.8 No.1, Februari 2008. 
Fama, Eugene F : 1978. "The Effects of a Firm Investment and Financing Decisions on The Walfare of its Security Holders". The Amirican Economic Review. 272-284.

Frank K. Really dan Keith C. Brown, 2000. Investment Analysis and Portofolio Management, Edisi ke-6, Amerika Serikat: Thompson Learning,Inc.

Hartono, J. 2010. Teori Portofolio dan Analisis Investasi (7 ed). Yogyakarta: BPFE.

Hartono, Jogiyanto, 2012. Teori Portofolio dan Analisis Investasi, Edisi 5, BPFE, Yogyakarta.

Hottagalng, Pretty, N. Analisis faktor-faktor yang mempengaruhi Price Earning Ratio Pada Perusahaan LQ45 di Indonesia. Universitas Sumatra Utara.

Irawati, Susan. 2006. Manajemen Keuangan. Cetakan Kesatu. Bandung: PT. Pustaka

Jogiyanto, (2000). Teori portofolio dan analisis investasi. Edisi kedua BPFE UGM, Yogyakarta.

Kamsir. 2010. Pengantar Manajemen Keuangan. Jakarta: Kencana Prenada Media Group.

Kim, E. Han. (1992). Miller's equilibrium, Shoreholder leverage clienteles, and optimum capital structure. The Journal of Financial. 37 (2):301-319.

Kotler, Philip and Nancy Lee. Corporate Social Responsibility: Doing the most Good for Your Company and Your Couse. New Jersy: John Willey \& Sanso Inc, 2005.

Kusumadilaga, Rimba. 2010. Pengaruh Corporate Social Responsibility Terhadap Nilai Perusahaan dengan Profitabilitas Sebagai Variabel Moderating (Studi Empiris Pada Perusahaan Manufaktur yang Terdaftar di Bursa Efek Indonesia). Skripsi. Fakultas Ekonomi, UNDIP Semarang.

Madigliani, F. and Miller, M.H. (1958). The Cost of Capital Corporation Finance and the Theory of Investment. American Economic Review. 47 (3): 261297.

Martono, Agus Harjito, 2005. Manajemen Keuangan. Edisi Pertama Cetakan Kelima. EKONISA, Yogyakarta. 
Mathews, M.R. (1995). "Social and Environment Accounting: A practical Demonstration of Ethical Concern". Journal of Business Ethies, Vol.14, PP 663-671.

Mulyadi. 2006. Auditing Buku 1, Jakarta: Salemba Empat.

Myers, Stewart C, (1977). Determinant of Corporate Borrowing. Journal of Financial Economic.

Purnamasari, Linda, dkk, "Interdependensi Antara Keputusan Investasi, Keputusan Pendanaan dan Keputusan Deviden, "Jurnal Keuangan dan Perbankan vol.13 No.1, 2009.

Rosiana, Gusti Ayu Made Ervina, dkk. 2013. Pengaruh Pengungkapan CSR Terhadap Nilai Perusahaan dengan Profitabilitas Sebagai Variabel Pemoderasi. E-Jurnal Akuntasi Universitas Udayana. Vol.5 No.5 No.3:723738.

Ross, Westerfield, Jordan (2006 Corporate Finance Fundamentals. $7^{\text {th }}$ ed. Newyork: McGrow-hill.

Suad, Husnan. 1996, Manajemen Keuangan Teori dan Penerapan (Keputusan Jangka Panjang). Edisi Keempat, Buku Pertama, Yogyakarta: BPFE UGM.

Sutopoyudo. 2009. Pengaruh Penerapan Corporate Social Responsibility (CSR) Terhadap Profitabilitas Perusahaan, Sutopoyudo's weblog at http://www.wordpress.com, Diakses tanggal 30 Oktober 2011.

Sutrisno, 2000. Manajemen Keuangan Modern. Bumi Aksara. Jakarta.

Tandelilin, Eduardus.2001. Analisis Investasi dan Manajemen Portofolio. Edisi Pertama Yogyakarta: BPFE.

Tandelilin, Eduardus. 2010. Portofolio dan Investasi Teori dan Aplikasi, Edisi Pertama, KANISIUS, Yogyakarta.

Wahyudi, dan Pawestri. 2006.'Implikasi Struktur Kepemilikan Terhadap Nilai Perusahaan dengan Keputusan Keuangan Sebagai Variabel Intervening". Simposium Nasional Akuntansi 9. Padang. 1-25.

Wijaya, Lihan Rini Puspita, Bandi Anas Wibawa, "Pengaruh Keputusan Investasi, Keputusan Pendanaan, Dan Kebijakan Deviden Terhadap Nilai Perusahaan,"Simposium Nasional Akuntansi XIII Purwokerto, 2010. 
Wijaya, Maria. 2012. Faktor-faktor yang Mempengaruhi Pengungkapan Tanggung Jawab Sosial Pada Perusahaan Manufaktur yang Terdaftar di Bursa Efek Indonesia. Jurnal Ilmiah Mahasiswa Akuntansi. Vol.1 No.1 Januari: 26-30.

http://id.wikipedia.org/wiki/URL

$\underline{\text { www.hukumonline.com }}$

www.idx.co.id. 